\title{
吃音検査法から見た成人吃音当事者の言語症状の様相
}

\author{
安崎 文子1,3) 柴崎 光世 ${ }^{2)}$ 山本佐代子 ${ }^{3)}$
}

要 約：成人の吃音当事者の実態を調べるため, 吃音を自覚し自助グループに参加している 成人 42 名を対象として吃音検査法 ${ }^{1)}$ を施行した。非流暢性頻度と重症度, 構音障害の有無や 音読スピードの評価, さらに中核症状頻度や音読スピードを変数としたWard 法を用いたクラ スター分析を行った。重症度では，16名（38.1\%）が正常からごく軽度であった一方，依然と して吃音を気にしている隠れ吃音についての検討の余地が残された。対象者の 14 名（33.3\%） が構音障害を重複しており，そのうち 13 名が側音化構音障害であった。また音読スピードの 速い群は, 幼児期に吃音を発症した割合が少ない傾向が考えられた. クラスター分析の結果, 4 グループに区分されグループ A から Dへと徐々に非流暢性は重症化していたが，必ずしも 区分されたグループと, 非流暢性頻度や重症度とは一致しなかった。 音読が改善や重症度を決 めるキー項目と推察された。

索引用語：成人吃音者, 吃音検査法, 側音化構音障害, 音読, クラスター分析

\section{Aspects of Speech Disorder in Adults who Stutter}

— Analysis of Results of the Japanese Standardized Test for Stuttering-

$$
\text { Fumiko Anzaki1 }{ }^{1,3} \text {, Mitsuyo Shibasakii }{ }^{2)} \text { and Sayoko Yamamoto }{ }^{3)}
$$

\begin{abstract}
We examined aspects of speech disorder in 42 adults (age: $31.5 \pm 13.4$ yr) who stuttered (AWSs) and who were aware of their stuttering. The Japanese Standardized Test for Stuttering was administered. From their utterances in the test, we analyzed the frequency and severity of their stuttering, and we checked for the presence of any speech sound disorder and the read aloud rate. Cluster analysis was also performed using the Ward method, with main stuttering symptoms and read aloud rate as variables. Sixteen subjects (38.1\%) with a main stuttering symptom showed normal oral fluency or a very mild level of stuttering. However, they were still suffering from stuttering. Fourteen subjects (33.3\%) had speech sound disorders along with stuttering. Among the 14 subjects with speech sound disorders, 13 subjects showed lateral articulation. Furthermore, our observations suggested that AWSs with a fast read aloud rate are less likely to have had onset in early childhood than AWSs in other groups. In the cluster analysis, the subjects divided into four groups, with non-fluency gradually increasing in severity from A group to D group. However, the
\end{abstract}

東京都市大学大学院総合理工学研究科 ${ }^{11}$ : = 158-8557 東京都世田谷区玉堤 1-28-1

明星大学心理学部心理学科 ${ }^{2)}$ : $=191-8506$ 東京都日野市程久保 2-1-1

NPO 法人 TBI リハビリテーションセンター ${ }^{3)}$ ：干110-0008 東京都台東区池之端 4-10-10

${ }^{1)}$ Graduate School of Engineering, Tokyo City University: 1-28-1 Tamazutsumi, Setagaya-ku, Tokyo 158-8557, Japan

${ }^{2}$ Department of Psychology, Meisei University: 2-1-1 Hodokubo, Hino City, Tokyo 191-8506, Japan

${ }^{3}$ Non-profit Organization TBI Rehabilitation Center: 4-10-10 Ikenohata, Taito-ku, Tokyo 110-0008, Japan

2018 年 6 月 1 日受稿 2018 年 8 月 29 日受理 
groups segmented according to cluster analysis did not necessarily agree with levels of nonfluency frequency and stuttering severity. In the A, B, and C groups, reading aloud was the easiest task, and conversely it was most difficult in D group. The read aloud task may be a key task that can be administered to predict improvement in the severity of stuttering.

Key words: stuttering, Japanese Standardized Test for Stuttering, speech sound disorder, read aloud task, cluster analysis

\section{はじめに}

吃音は, 発達性の吃音と獲得性（神経原性·心因性） の吃音に分類される ${ }^{2,3)}$. 発達性吃音の発症率は約 $5 \%$ 前後だが，有病率は約 $1 \%$ であり自然治瘉も考えられ ている ${ }^{4}$. 小児期発症流暢症の縦断研究では $85 \%$ の子 どもたちが非流暢性から回復したとの報告も見られ る5). しかし，こうした自然治癒の報告に反して潜行 的に重症化していく例も多く，不適応で相談に来る ケースも見られる。吃音をもつ成人の $40 \%$ が社交不 安障害を有することも報告されている 初頭音の繰り返しが多く, 重症化に伴い徐々に詰まる 阻止へといたるといわ机る，だが，成長し語彙が増え ると、吃音になりやすい音が決まってくることもあり， そうした音を避けて文を作り替えるなど，隠すことが 上手になる。したがって吃音をもつ成人の真実の吃音 症状は不確かである。

同じ吃音症例でも言語 language ・発話 speech とも にばらつきが大きい，音読・自発語で言語モダリティ 別の個人内差, 機能的構音障害の重複7), 発達障害の 重複8)，注意や認知面の問題等について報告されてい る。また, クラッタリング9) (早口症) の症例も多く, 吃音の下位グループとの見方もある ${ }^{10}$.

このように吃音はさまざまな問題点を有するが, 成 人した吃音当事者の実態については，詳細な報告はま だ少ない，そこで，本研究では，成人吃音当事者の言 語症状の様相について, 吃音検査法を用いて検討した ので報告する.

\section{対 象 者}

2015 2016 年に, 東京言友会, および横浜言友会 に参加した 18〜 67 歳の吃音を自覚する成人当事者 42 例（平均年齢 31.5 歳 \pm 13.4 , 男性 36 名, 女性 6 名） である。利き手について，1例は完全左利き，4例は 左利きを幼児期に右利きに矯正した両手利きであった が，それ以外は右利きだった。

なお，本研究を実施するにあたり，大和大学倫理委
員会の倫理審査の承認を得た。また，東京言友会・横 浜言友会に依頼し研究の許可を得た，さらに実施にあ たっては本人より書面にて同意を得た.

\section{方法}

日本語版吃音検査法 ${ }^{1)}$ を行い, そのなかから，基本 検査である「文・文章による絵の説明」「自由会話」「文 章音読」について検査時の発話を評価対象とし, 重症 度も発話の重症度で確認した。今回は，吃音検査法の 評価手順に従って対象者の基本的情報，課題別の非流 暢性の差と重症度を分析した後，さらに構音障害の重 複の様相, 文章音読スピード, 課題別の吃音の出現頻 度と音読スピードを変数としたクラスター分析 (Ward 法）によるグループ分けを試みた。

基本的情報では，発吃年齢と家族性の有無，病歴， 利き手の確認を行った。ただし，発吃年齢，および両 親祖父母兄弟の血縁の 2 親等以内の親族で吃音を有す る者の有無は，吃音当事者の自己申告に従った，分析 にあたっては，すべての発話をヴォイスレコーダー (Olympus VoiceTrek V-823) に録音した。録音され た音声は，音声解析ソフトAudacity（The Audacity Team 開発，フリーソフト）を用いて繰り返し2 回聴 取・書き出した。書き出された発話は中核症状につい ては,「音・モーラ・音節の繰り返し (sound, mora, syllable repetition, 以下 SR), 語の部分の繰り返し (part-word repetition, 以下 PWR), 引き伸ばし (prolongation, 以下 $\mathrm{Pr}$ ), 阻止 (block, 以下 $\mathrm{Bl}$ ), さ らに，その他の非流暢性については，「語句の繰り返 L (word repetition, 以下 WR), 挿入 (interjection, 以下 $\mathrm{Ij}$ ), 言い直 $L$ (revision, 以下 Rv), 中止 (incomplete, 以下 Ic), 途切れ (以下 $\mathrm{Br}$ ), 間（以下 $\mathrm{Pa}) 」 に$ 分類された，基本検査での全文節数を母数と して非流暢性の出現率が算出された。2 回の非流暢性 出現率をクロンバック $a$ にて確認したところ 0.937 と なり，再現性は確認された。また，構音障害が疑われ る置換や歪については，聴取と鼻息鏡なども用いて構 音動作の確認を行い，さらに録音した音声にて再確認 
表 1 対象者の基礎確認事項

\begin{tabular}{|c|c|}
\hline 基礎確認事項 & 全人数 42 名（\%） \\
\hline 性別 & 男性 36 名（85.7），女性 6 名（14.3） \\
\hline 利き手 & 右利き 37 名（88.1）, 両手利き 4 名（9.5）, 完全左利き 1 名（2.4） \\
\hline 発吃年齢（本人の自覚） & $\begin{array}{l}\text { 小学校低学年までに自覚34名 (81.0), 小学校高学年で自覚3名 }(7.1) \text {, } \\
\text { 中学で自覚 } 1 \text { 名 (2.4), 高校·大学生で自覚 } 4 \text { 名 (9.5) }\end{array}$ \\
\hline 家族性の有無（2 親等以内, 自己申告) & 家族性あり 14 名（33.3），なしあるいは不明 28 名（66.7） \\
\hline
\end{tabular}

表 2 重症度別人数

\begin{tabular}{|c|c|c|c|c|}
\hline & 中核症状頻度による分類基準 & 人数（\%) & 総非流暢性頻度による分類基準 & 人数 $(\%)$ \\
\hline 正常 & 0～3\%未満 & $9(21.4)$ & $0 \sim 12 \%$ 未満 & $15(35.7)$ \\
\hline ごく軽度 & 3〜 5\%未満 & $7(16.7)$ & $12 \sim 14 \%$ 未満 & $3(7.1)$ \\
\hline 軽度 & 5～12\%未満 & $14(33.3)$ & $14 \sim 22 \%$ 未満 & $9(21.4)$ \\
\hline 中度 & 12～37\%未満 & $11(26.2)$ & $22 \sim 50 \%$ 未満 & $13(31.0)$ \\
\hline 重度 & 37〜 71\%未満 & $1(2.4)$ & $50 ＼mathrm{~ 90 \% 未 満 ~}$ & $2(4.8)$ \\
\hline
\end{tabular}

表 3 基本検査の平均中核症状頻度と平均総非流暢性頻度

\begin{tabular}{|c|c|c|c|c|c|c|c|c|c|c|c|c|c|c|}
\hline \multicolumn{7}{|c|}{ 平均中核症状頻度（\%） } & \multicolumn{8}{|c|}{ その他の平均非流暢性頻度（\%） } \\
\hline & $\mathrm{SR}^{1)}$ & $\mathrm{PWR}^{2)}$ & $\operatorname{Pr}^{3)}$ & $\mathrm{Bl}^{4)}$ & $\begin{array}{l}\text { 平均中核症 } \\
\text { 状頻度合計 }\end{array}$ & & $\mathrm{WR}^{5)}$ & $\mathrm{Ij}^{6)}$ & $\mathrm{Rv}^{7)}$ & $\mathrm{Ic}^{8)}$ & $\mathrm{Br}^{9)}$ & $\mathrm{Pa}^{10)}$ & $\begin{array}{l}\text { 平均総非流 } \\
\text { 暢性合計 }\end{array}$ & \\
\hline 自由会話 & 5.53 & 0.54 & 0.90 & 4.96 & 11.79 & & 1.25 & 4.74 & 0.44 & 0.60 & 0.57 & 0.33 & 19.72 & \\
\hline 絵の説明 & 4.45 & 0.92 & 0.86 & 4.94 & $10.747 *$ & $* *$ & 1.98 & 9.25 & 1.18 & 0.72 & 0.83 & 0.66 & $25.37-$ & $* *$ \\
\hline 文章音読 & 2.10 & 0.24 & 1.43 & 2.95 & $6.71^{]^{*}}$ & & 0.43 & 0.57 & 0.52 & 0.05 & 0.86 & 1.24 & 10.38 & \\
\hline
\end{tabular}

$\mathrm{SR}^{1)}$; 音・音節の繰り返し, $\mathrm{PWR}^{2)}$; 語の部分の繰り返し, $\mathrm{Pr}^{3)}$; 引き伸ばし, $\mathrm{Bl}^{4)}$; 阻止, $\mathrm{WR}^{5)}$; 語句の繰り返し, $\mathrm{Ij}^{6)}$; 挿入, $\mathrm{Rv}^{7)}$; 言い直し, $\mathrm{Ic}^{8)}$; 中止, $\mathrm{Br}^{9)}$; 途切れ, $\mathrm{Pa}^{10)}$; 間。 *有意差あり $\mathrm{p}<.05$, **有意差あり $\mathrm{p}<.01$

した，音読スピードも，上記音声解析ソフトを用いて 計測した。

\section{結果}

\section{1 . 対象者の基本的情報}

表 1 に基本情報を示した，対象者となる成人吃音当 事者の男女比は, 男性 36 名, 女性 6 名で, 6:1 であっ た。利き手は右利きが 37 名で約 9 割，左利きを右利 きに矯正し，エジンバラの利き手指数 ${ }^{11)}$ では 80 を示 したものが 4 名, 完全左利きが 1 名であった。発吃を 当事者本人が自覚した年齢は，34 名 $(81.0 \%)$ が小学 生低学年までに自覚があり, 残りの 2 割がそれ以降の 自覚で,そのうち高校・大学での自覚は 4 名 (9.5\%) であった。両親・祖父母・兄弟の 2 親等以内の親族に 吃音症状を示したものは 14 名（33.3\%）であった.

\section{2. 吃音検査法 重症度別分類}

表 2 に重症度別人数を示した，正常あるいはごく軽 度を併せると, 中核症状による重症度分類の基準 ${ }^{1)}$ で は 16 名 $(38.1 \%)$, 中核症状とその他の非流暢性を合 計した総非流暢性頻度による分類基準 ${ }^{1)}$ でも 18 名 （42.8\%）を占めた。重症度分類で最も多い重症度は, 中核症状別分類では軽度 14 名 (33.3\%), 総非流暢性
頻度による分類では正常 15 名（35.7\%）であった。 重度例は中核症状による分類ではわずか 1 名（2.4\%） であった。

\section{3 . 基本的検査の課題別非流暢性出現頻度}

表 3 に, 基本検査「絵の説明」「文章音読」「自由会 話」において出現した中核症状「音・モーラ・音節の 繰り返し (SR)，語の部分の繰り返し（PWR），引き 伸ばし (Pr), 阻止（Bl）」また, その他の非流暢性「語 句の繰り返し (WR), 挿入 ( Ij), 言い直し $(\mathrm{Rv})$, 中 止 $(\mathrm{Ic})$, 途切れ $(\mathrm{Br})$, 間 $(\mathrm{Pa}) 」$ の各平均出現頻度 を示した。ささらに, 平均中核症状出現頻度合計と, 中 核症状出現頻度合計とその他の平均非流暢性出現頻度 を合計した平均総非流暢性出現頻度について示した。 各出現頻度は出現した非流暢性の課題別回数を課題ご とに総文節数で割り算出した。

非流暢性別に見ると，音・音節の繰り返し（SR） と阻止 (Bl) の出現が多かった。また挿入 (Ij)も多かっ た. 中核症状出現頻度と総非流暢性出現頻度について, 基本検査を要因とする対応のある一元配置の分散分析 をそれぞれ行った。そ結果 Mauchlyの球面性仮説 が成り立たなかったため, Greenhouse-Geisser を利用 して自由度を修正した。中核症状の合計，総非流暢性 


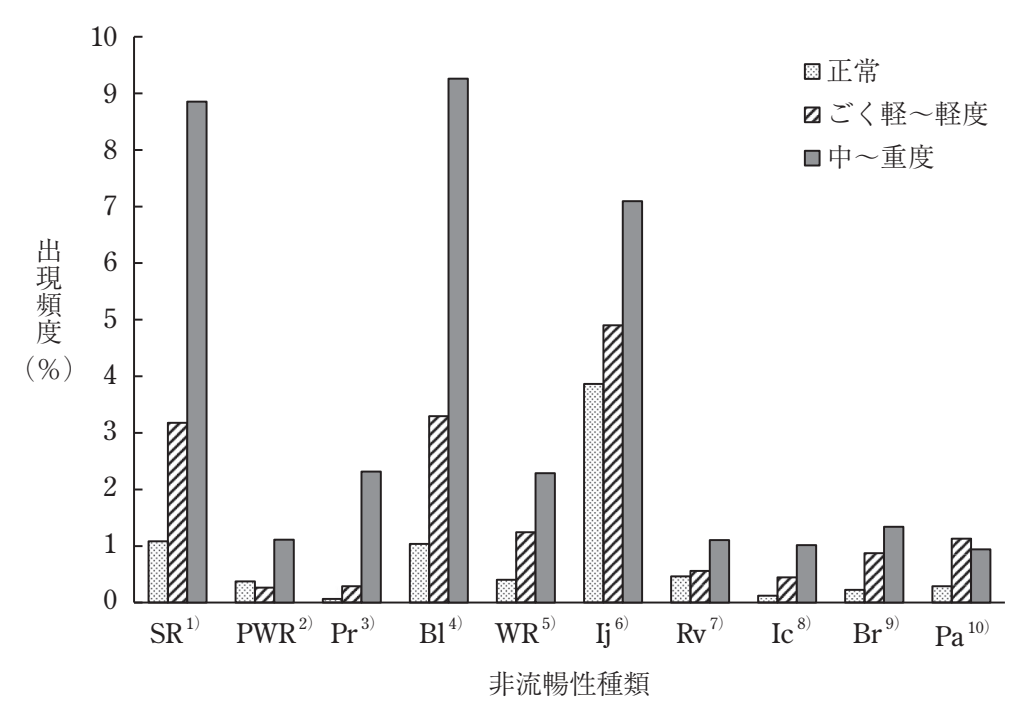

図 1 重症度別非流暢性の平均出現頻度

$\mathrm{SR}^{1)}$; 音・音節の繰り返し, $\mathrm{PWR}^{2)}$; 語の部分の繰り返し, $\mathrm{Pr}^{3)}$; 引き伸 ばし, $\mathrm{Bl}^{4)}$; 阻止, $\mathrm{WR}^{5)}$; 語句の繰り返し, $\mathrm{Ij}^{6}{ }^{6}$; 挿入, $\mathrm{Rv}^{7)}$; 言い直し, $\mathrm{Ic}^{8)}$; 中止, $\mathrm{Br}^{9)}$; 途切れ, $\mathrm{Pa}^{10)}$; 間

表 4 構音障害の種類とその出現頻度

\begin{tabular}{|c|c|c|}
\hline 構音障害の種類 & 人数と中核症状による重症度内訳 & $\begin{array}{l}\text { 側音化構音とそれ以外 } \\
\text { の構音障害の人数 (\%) }\end{array}$ \\
\hline 側音化の歪 & $\begin{array}{l}7 \text { 名（正常 } 1, \text { ごく軽度 } 1 \text {, 軽度 } 2, \\
\text { 中度 } 2 \text {, 重度 } 1)\end{array}$ & \\
\hline 側音化+口蓋化の歪 & 4 名（正常 3, 軽度 1） & $13(31.0)$ \\
\hline 側音化+歯間化の歪 & 1 名（軽度） & \\
\hline 側音化 + 運動障害性構音障害疑い（開鼻声や流涎等） & 1 名（中度） & \\
\hline 運動障害性構音障害疑い（開鼻声や流涎等） & 1名（軽度） & $1(2.3)$ \\
\hline 合計 & & $14(33.3)$ \\
\hline
\end{tabular}

の合計のいずれについても課題の主効果が有意であっ た（中核症状の合計: $\mathrm{F}(1.713,70.229)=5.308, \mathrm{p}<.05$, 総非流暢性の合計 $: \mathrm{F}(1.662,68.122)=17.836, \mathrm{p}<.01)$. Tukey b を用いた多重比較では, 中核症状頻度では, 「音読」と「自由会話」との間 $(\mathrm{p}<.01)$,「音読」と「絵 の説明」との間（ $\mathrm{p}<.05 ） に$ 有意差があり，また総非 流暢性頻度では,「音読」と「自由会話」,「音読」と「絵 の説明」との間に有意差が示された(いずれも $\mathrm{p}<.01$ ). 音読課題での非流暢性の出現が少ないことが示され た。

\section{4 . 基本検査の重症度別非流暢性の出現}

図 1 に基本検査の重症度別非流暢性の平均出現頻度 を示した，横軸に重症度別の非流暢性種類，縦軸に平 均出現頻度（\%）を示した。中核症状である SR と $\mathrm{Bl}$ は中〜重度群で多く，一方 Ij は正常からごく軽度の 群でも全般的に多かった。

\section{5. 構音障害の出現割合}

表 4 に今回の研究で確認された構音障害の種類とそ
の出現頻度を示した。“歪を伴う阻止”による構音の 歪を除き，全体では 14 名（33.3\%）に，吃音に構音 障害が重複し，内訳では，イ列，特に/ri/や/6i/の 側音化の歪を示す者が 13 名と最も多かった。また開 鼻声や運動障害性構音障害が疑われる当事者も見られ た，構音障害を重複する対象者の吃音の中核症状によ る重症度の内訳では, 検査時にほとんど吃音の出現し なかった正常の範囲から重度までばらつきが大きかっ た。

\section{6 . 文章音読検査の音読スピード}

苅安 ${ }^{12)}$ の正常音読スピードに扔けるモーラ数/秒 を参考に, 今回の対象者の音読スピードを, 正常範囲 より遅い，正常範囲，正常範囲より速い，の 3 群に分 類した。表 5 に文章音読検査の音読スピードと重症度 および発吃自覚時期を示した。音読スピードの遅い群 では，中〜重度の非流暢性を示す者が 4 名で 3 割を占 めていたが，正常範囲とごく軽度の非流暢性を示す者 も2名見られた。また発吃自覚時期は全例小学校低学 
表 5 文章音読検査の音読スピードと重症度および発吃自覚時期

\begin{tabular}{|c|c|c|c|c|}
\hline 速さ & モーラ数/秒 & 人数 & 基本検査中核症状 重症度内訳人数 & 発吃自覚時期別人数（\%） \\
\hline 遅い & 4.93 モーラ/秒未満 & 12 & 正常 1 , ごく軽度 1 , 軽度 6 , 中度 3 , 重度 1 & 小学校低学年まで $12 （ 100 ）$ \\
\hline 正常範囲 & 4.93〜6.77 モーラ/秒 & 23 & 正常 7, ごく軽度 5 , 軽度 4 , 中度 7 & $\begin{array}{l}\text { 小学校低学年まで } 19 \text { (82.7) } \\
\text { 小学校高学年 } 1 \text { (4.3) } \\
\text { 中学 } 1 \text { (4.3) } \\
\text { 高校大学 } 2 \text { (8.7) }\end{array}$ \\
\hline 速い & 6.77 モーラ/秒以上 & 7 & 正常 1 , ごく軽度 1 , 軽度 4 , 中度 1 & $\begin{array}{l}\text { 小学校低学年まで } 3(42.8) \\
\text { 小学校高学年 } 2 \text { (28.6) } \\
\text { 高校大学 } 2 \text { 2(28.6) }\end{array}$ \\
\hline
\end{tabular}

年までであった，正常範囲の音読スピードを示す対象 者は，正常範囲の非流暢性を示す者は 7 名と最も多 かったが，中度の非流暢性を示す者も 7 名だった，発 吃自覚時期は小学校低学年までが 19 名 $(82.6 \%)$, 高 学年・中学・高校大学が 4 名 (17.6\%) だった。音読 スピードの速い群は 7 名だったが，非流暢性は軽度を 示す者が 4 名と最も多く, 正常から中度まで 1 名ずつ 見られた。発吃自覚時期は 7 名のうち, 小学校低学年 までの自覚が 3 名 $(42.8 \%)$ で半分以下の低い割合だっ た.

\section{7. 吃音の基本検査から見たクラスター分析}

図 2 に, 音読時 1 秒当たりのモーラ数, 基本検査の 中核症状出現頻度を变数としたWard 法を用いたクラ スター分析によるデンドログラムを示した. ABCD の 4 つのグループに区分された.

図 3 に，4つに区分されたグループ別の中核症状非 流暢性頻度と重症度を示した。横軸は基本検査の中核 症状非流暢性頻度（\%), 縦軸は中核症状による重症 度 (1: 正常, $2:$ ごく軽度, $3:$ 軽度, 4: 中度, 5 : 重度)を示した.クラスター分析で区分された各グルー プ別に各当事者を中核症状と重症度によりプロットし た。図 3 より，Aグループは正常から軽度，Bグルー プはごく軽度から中度，Cグループは全例中度，D グ ループは中度と重度となった。重症度別に見ると，正 常 1 とごく軽度 2 は A グループだけだが, 軽度 3 は A B グループが混在，また中度 4 においては，特に中核 症状出現頻度で $20 \%$ 前後にB・C・D グループの者が 混在していたＡ から D グループへと徐々に非流暢 性は重症化していたものの，必ずしもクラスターで区 分されたグループと, 非流暢性頻度と重症度は一致し なかった。

図 4 に, クラスター分析により区分されたグループ 別平均音読スピードと課題別中核症状の平均非流暢性 頻度を示した. 図 4 の横軸はグループごとの課題, 左 縦軸は中核症状平均非流暢性頻度（\%)，右縦軸は音

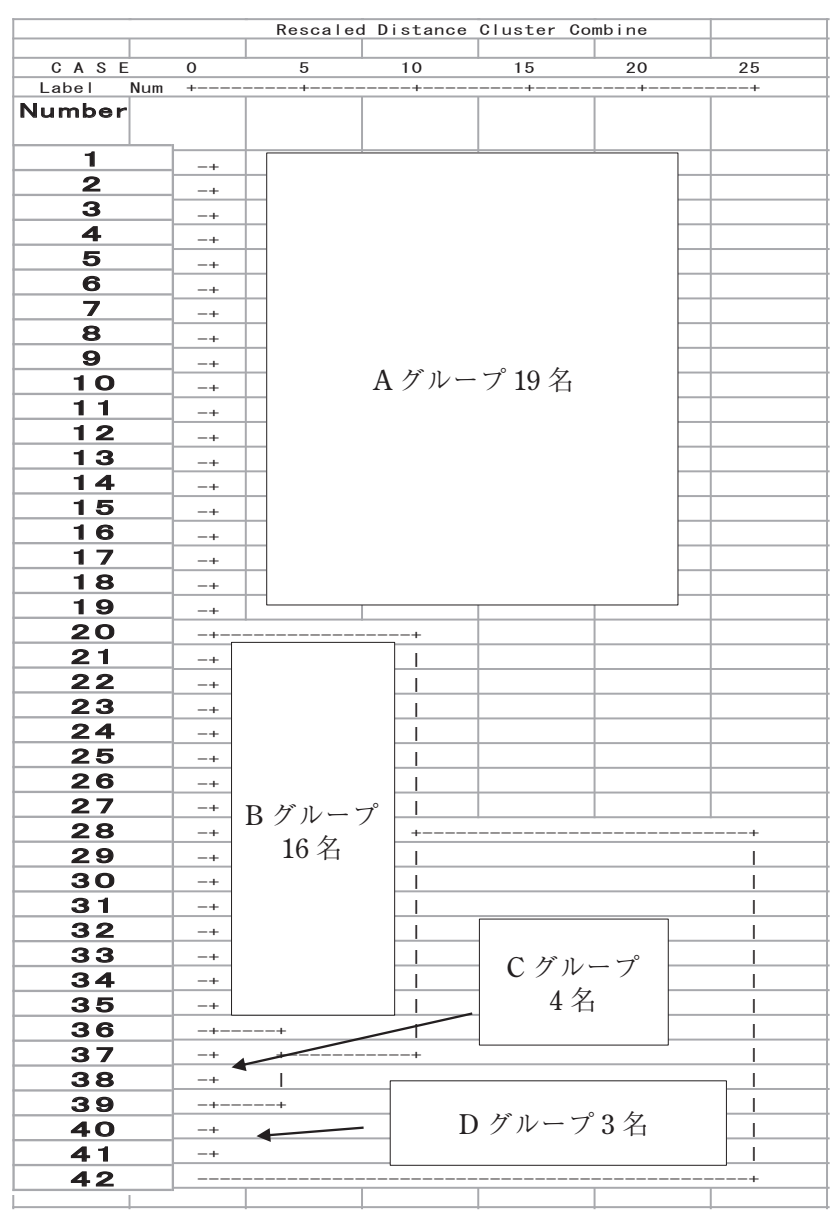

図 2 音読スピードと基本検査の中核症状頻度を変数とする デンドログラム（Ward 法）

読スピード (平均モーラ数/1 秒)を示したＡグルー プから徐々に非流暢性の高くなる B と C グループで は，音読が最も非流暢性が低く容易な課題であり，絵 の説明, 自由会話の順に非流暢性が高くなっていた。 一方，Dグループは 3 名だが，逆に音読の非流暢性が 高く困難な課題であり, 絵の説明, 自由会話と非流暢 性が低くなっていた，各課題（音読，絵の説明，自由 会話）に対する中核症状出現頻度と音読 1 秒当たりの モーラ数について, グループを要因とする一元配置の 


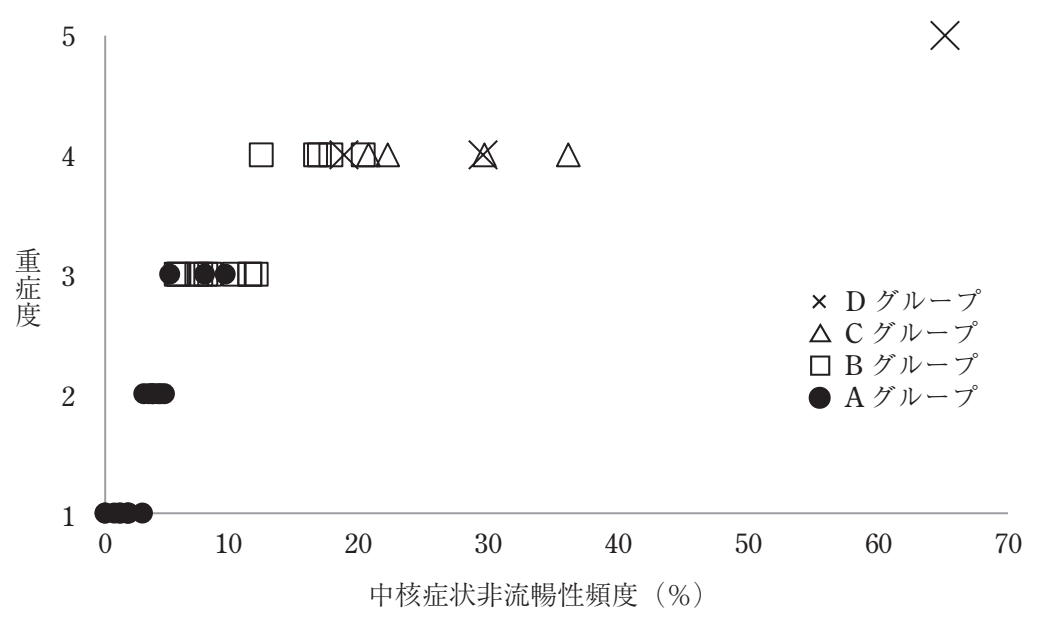

図 3 グループ別の中核症状非流暢性頻度と重症度 基本検査中核症状非流暢性頻度による重症度：1；正常（0～3\%未満），2； ごく軽度（3～5\%未満度)，3; 軽度（5～12\%未満），4；中度（12～37\%未満）， 5 ; 重度（37～71\%未満）

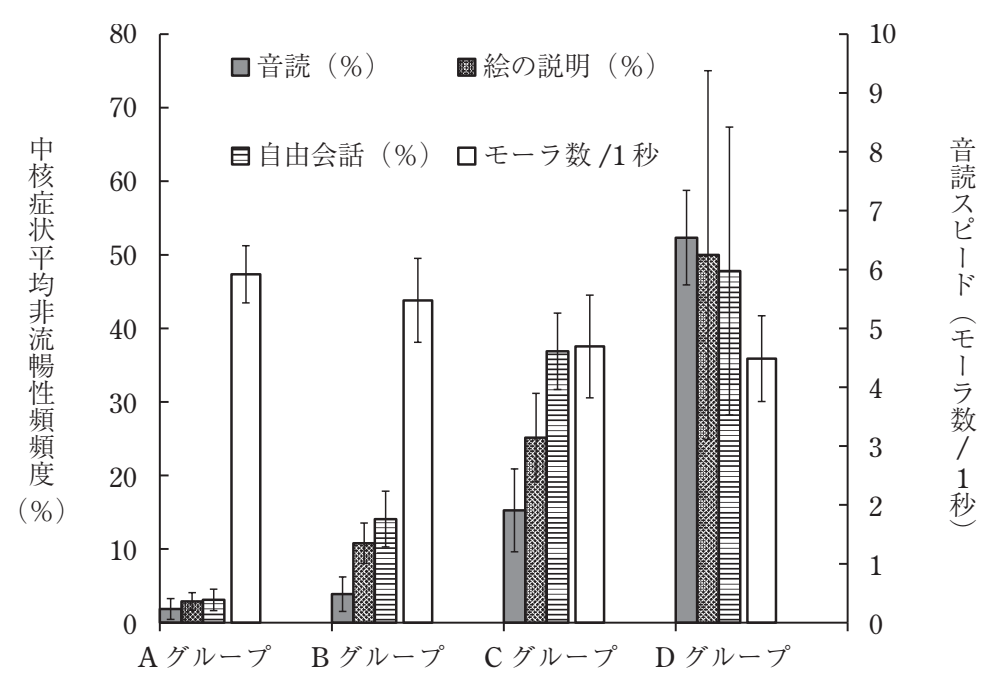

図 4 グループ別平均音読スピードと課題別中核症状の平均非流暢性頻度 誤差範囲は標準偏差を示す.

分散分析を行った。 その結果, 1 秒当たりのモーラ数 に関してグループの主効果が有意ではなかった（F（3, $38)=1.864, \mathrm{p}=.15)$. 各課題（音読, 絵の説明, 自由 会話）の中核症状出現頻度に関しては, グループの主 効果がいずれの課題でも有意だった（音読課題：F (3, $38)=75.729, \mathrm{p}<.01$, 絵の説明 : $\mathrm{F}(3,38)=13.917, \mathrm{p}$ $<.01$, 自由会話 : $(\mathrm{F}(3,38)=23.333, \mathrm{p}<.01)$. Tukeyによる多重比較では, 音読では A と B グルー プ間以外のすべての組み合わせにおいて有意差が認め られた $(\mathrm{p}<.01)$. 絵の説明では $\mathrm{A}$ グループと C グルー プ, A グループと D グループ, B グループと D グルー プ間で有意差が認められた（A グループと C グルー プで $\mathrm{p}<.05, \mathrm{~A}$ グループと D グループ， B グループ
と D グループで $\mathrm{p}<.01)$ ．自由会話ではすべてのグ ループ間で有意差が認められた（A グループと B グ ループで $\mathrm{p}<.05$ ，それ以外のグループの組み合わせで はすべて $\mathrm{p}<.01)$.

\section{考察}

\section{1 . 基本情報に関して}

今回の検査の基本情報から，左利きおよび左利きか らの矯正が 5 名で全体の $12 \%$ だった。一般的に左利 きの割合は約 10〜 $12 \%$ といわれており ${ }^{13)}$ ，今回の結 果では，吃音の有無にかかわらず左利きの割合は変わ らないと考えられる。

自己申告の発吃年齢ではあるが，34 名 (80.9\%) が 
小学校低学年頃までと申告していた。吃音は最も発症 しやすい時期が 2 5 歳にかけての時期であると報告 されている ${ }^{14)}$. 今回の評価はあくまでも本人の自覚年 齢である。発吃についての本人の自覚「2 次吃」は, 親の発症の気づき「1 次吃」の年齢より平均 2.7 歳遅 いと報告されている ${ }^{15)}$. したがって親の気づきとのず れを考慮しても, 最も発症しやすい幼児期に発吃した 可能性の高い当事者が多かったことが考えられる，高 校・大学での気づきとなる当事者に関しては, 発吃の 機序として心因性の問題を訴える傾向が見られたが精 查は行わなかった。

またあくまでも自己申告だが，2 親等内の血縁者に

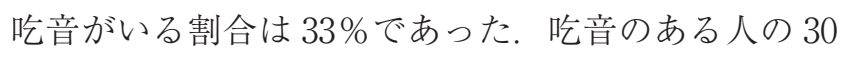
～60\%に吃音の家族歴があることが報告されている が16), 今回の結果は不確実性が大きく判断は難しい.

\section{2. 吃音検査法 重症度別分類}

重症度は中核症状と総非流暢性のそれぞれの頻度で 多少重症度が異なるが，いずれの評価方法でも正常お よびごく軽度を併せて約 4 割となった，軽度と中度は それぞれ 2〜3 割, 重度は $5 \%$ にも満たなかった。今 回の調査はコホート法ではないので経過は不明だが, 成人になると，吃音は軽度化することが報告されてい る ${ }^{17)}$. 今回の調査においては 50 代以上の当事者 5 名 のうち 4 名が,「若い頃に比べると吃音が大分楽になっ た」と話し, 非流暢性頻度も標準範囲であった。さら に, 訓練による効果か「言葉の教室で徹底的にゆっく り話すことを指導された」と振り返り, 検査でも吃音 が出現しなかった対象者もおり, 適切な介入の効果に ついて貴重な示唆であると思われる。

しかし，考え方を変えると，吃音がきちんとコント ロールできている当事者にもかかわらず，常に支援を 求め, 発語の苦しさを訴えている。言友会に参加して いる当事者の約 4 割が，吃音がほほ出現しない，ある いは気づかないほど軽度であっても, 成人になっても 自身の吃音を忘れることがない，つまり気にしている ことを意味する，成人にいたると隠すことが上手にな ることも考えられるが，その分，話すことに気を遣い 疲れる。ここで, 推察されることは, 隠れ吃音と社交 不安障害である。また成人吃音症例では不安や抑うつ 気分が有意に高く, 社交不安障害の発症率が高いこと も報告されている ${ }^{18,19)}$. 今回の当時者の 4 割すべてが 社交不安か否かは精查していない, 吃音を自覚する成 人の多くが, 改めて単なる言葉のみの障害ではないこ とを示唆する。

\section{3 . 基本的検査の課題別非流暢性出現と重症度}

課題別に見ると,「文章音読」の非流暢性頻度が有 意に少なかった，絵の説明と自由会話での非流暢性に 差はなかった，視覚的な言語でのフィードバックは吃 音を減少させると報告されている ${ }^{20)}$. 半分近くの当時 者より「音読では吃音は出ない」との意見も得たが, 一方で言語モダリティ別に難易度の差はないという当 事者もいた，軽度と中度の各 1 名からは，音読は言葉 を変えることができないのでより困難であるとの意見 も得た，また，以前は音読も苦手であったが，成人に なり，今は楽になったとの意見は多かった，吃音の機 序そのものが，単一の原因ではないと思われるが，視 覚的な入力が構音産生に良い効果を及ぼしやすいとも 考えられる。

今回の基本検査の重症度別非流暢性では, 阻止 $\mathrm{Bl}$ と音・音節の繰り返し SR の頻度が高かった，成人に なると，また重症になるほど $\mathrm{Bl}$ の比率が高くなると いわれるが3)，今回の結果では SR と Bl での大きな差 はなかった。また挿入句 Ij の比率は全般に高く，Ijが 流暢性に何らかの効果を及ぼしている可能性も考えら れる。

\section{4. 構音障害の種類とその出現頻度に関して}

今回の成人吃音当時者では, 構音障害を有する者は $33 \%$ となった，小児吃音例の構音障害合併率は $30 \%$ から $40 \%$ までと報告されている ${ }^{21)}$. 今回の成人の構 音障害合併率とほぼ同様の割合であった。この結果か ら，小児から成人にいたるまでの間に構音障害が完治 されていないことが推察される。肾の表出言語の発 達に問題をもつ子どもは，小児全体の $6 \%$ に当たり， そのうちの $90 \%$ がいわゆる語音障害 (SSD; Speech sound disorder) と報告されている22). 本邦でも同様に, 小児の機能性と言語（音韻）性の構音障害を合わせた 語音障害 SSD は, 幼児の $5 \%$, 学童・青年期の $1 \%$ と 推定されている ${ }^{23)}$. これに比べると, 吃音対象者で構 音障害の占める割合はきわめて高いと考えられる。機 能的構音障害の原因については十分明らかにされてい ないが, 語音弁別24,25) や随意運動の関与26) が指摘さ れている。ささらに兄弟で同様の構音障害を呈する症例 も報告されており ${ }^{27)}$, 器質的・環境的背景も考えられ る.

今回の対象者では，ほとんどがイ列の歪を示す側音 化構音障害であった。側音化構音は，口蓋裂児童にも 出現する構音障害だが, 機能的構音障害について学童 を対象とした調査では, 機能的構音障害全体の $22.4 \%$, 構音障害のなかでの比率は $55.3 \%$ で漸増傾向 
にあると報告されている28)。歯列不正との関連も示唆 されているが29,30)，発現の原因は特定されていない． 自然治癒はほほなく構音訓練の対象とされ，かつ治癒 に時間が掛かる。側音化構音以外では，口蓋化や歯間 化，さらには流涎や開鼻声など運動障害性構音障害の 疑われる当事者も見られた。今回の調査で構音障害を 示した当事者は全例が先天性・後天性の疾患は明らか ではない語音の産出の障害として SSD に当てはまる と考えられた。今回は構音障害の自覚について調査は 行っていないが “滑舌の悪さ”を直接訴えた構音障害 を伴う当時者は 2 名であった。いずれにせよ明暸度は 良好ではなく，聞き返される一因にもなりやすい，発 語にますます自信をなくす一要因になると思われる。

また，構音障害を併せ持つ当時者は，吃音の重症度 に関係なく全般にばらついて出現していた，吃音の発 生と構音障害の発生の機序は同じとは思われないが, 音韻障害を併せ持つ吃音児では音韻障害を重複しない 吃音児と比べて協調運動に問題をもつことが報告され ている ${ }^{31)}$ 。しかし，構音障害のみの原因についても前 述のとおり随意運動の関与が考えられている.

また，聴覚のモニタリングと音韻と発語運動の過程 は小児の発語運動の障害に密接にかかわっていると報 告されている22)，女览であり，音韻能力の高いことが, 吃音の改善と関連が高いことも報告されているが322, いずれにせよ今回際立って多かった側音化構音障害の みの原因, 側音化構音障害と吃音との関連について, 協調運動や聴覚モニタリングも含めてさらに精査が必 要であると思われる。

\section{5. 音読スピードと発吃自覚時期}

音読スピードは，全体に遅いグループは，吃音のた めに滞りがちになることも含め, 12 名中 10 名が軽度 以上で重症度は高かった。また全例発吃自覚時期は小 学校低学年までで，難治性の症状を示す者もいた，標 準のスピードの群は，正常またはごく軽度の重症度を 示す割合が 23 名中 12 名で約半分と最も多く, 残りの 半分が軽度以上だった。標準スピード群では，小学校 低学年までの自覚は $82.7 \%$ であり，中学と高校で自覚 した 2 名は明らかに早口を自覚していたが，音読時に は意図的にコントロールできていた。音読スピードが 速い群は 7 名で統計的には十分ではないが，小学校低 学年までの自覚は 3 名 $(42.8 \%)$ と 3 群で最も低かった。 発吃自覚時期が高校大学は 2 名 $(28.6 \%)$, 小学校高 学年以上も 2 名 $(28.6 \%)$ であり，発吃についての当 事者本人の自覚は，親の気づきより平均 2.7 年遅いと の “ずれ” 15) を考慮しても，幼児期の発症可能性の割
合は他の群より低いと思われる。標準スピード群で明 らかに早口だが音読時コントロール可能で，中学と高 校大学発吃自覚の 2 名も含めると, 発話スピードの速 い群の発症は幼児期を過ぎてからが多い可能性が考え られる。

クラッタリング（早口症）は発話速度が速くて聞き 取れない，構音速度の不規則さを特徵とするといわれ る ${ }^{9)}$. 吃音を主訴とする児童の $15.9 \%$ がクラッタリン グ（早口症）に相当したとの報告もある ${ }^{33)}$. 今回は， 発話速度の速さは計測したが，不規則さまでは精査し ていないため，単なる音読スピードである，音読が速 い群で，発吃自覚時期が高校大学の 2 名のうち 1 名は クラッタリングが強く疑われた。早口は言い誤りの引 き金となりやすい。また前述のように，早くて聞き取 れない場合もある。早口での言い詔り・不明瞭という 言語面での弱点から, 聞き返されて言い直し, 自信を 失うというコミュニケーションの悪循環が生じやすい と考えられる。

\section{6. 吃音の基本検査から見たクラスター分析}

今回の対象者について，音読スピード（1秒当たり のモーラ数), 基本検査の中核症状頻度を変数として, グループ分けをしたところ，4つのグループに分かれ た、A から D グループへと徐々に非流暢性は重症化 していたものの，必ずしもクラスターで区分されたグ ループと, 非流暢性頻度と重症度とは一致しなかった。 したがって，重症度分類だけでは分析できない区分分 けを，クラスター分析で示すことができたと考えられ る.

区分された各グループ別の音読スピードと平均中核 症状頻度については, A と B グループは音読スピー ドが標準から速めも含む。音読は $\mathrm{A}$ グループも $\mathrm{B}$ グ ループも比較的良好であったＡとＢグループの違 いはB グループの絵の説明と自由会話での非流暢性 の高さだった，Cグループは，B グループに比べると， 全体的に非流暢性が高いが，Cグループ内でのグルー プ内差では，音読が比較的良好に保たれていた，Dグ ループはすべての課題で非流暢性が高かった.さらに, $\mathrm{ABC}$ グループでは音読＜絵の説明＜自由会話の順に 非流暢性が高くなるのに対して，D グループでは逆に 音読の非流暢性が高く，音読>絵の説明 $>$ 自由会話の 順に非流暢性が低下していた。

以上のことから，自由会話が最も難しく音読は非流 暢性が低く話しやすいと考えられる一方で，D グルー プでは逆に音読が難しく，重症度や改善に関するキー 項目とも推察される。吃音症例では聴覚入力の問題 34 
や，視覚による言語が入力しやすいこと年）も指摘さ れており, 音読から改善していくという経過も推察で きる、 $\mathrm{ABC}$ のグループでは，最も伝えたい話をまと めることと，言いにくい言葉を避けることの両方に気 を遣う自由会話や絵の説明よりも，決まった文の音読 のほうが話しやすいものと思われた，一方で, Dグルー プの場合は，音読時の文字出力レキシコンから音韻出 カレキシコンや出力配列にいたる出力系に問題がある 可能性，またさらに入力から出力にいたる広範な問題 がある可能性が推察される，今後検討する必要がある と考えられ，また症候群としての吃音の機序の複雑さ が示唆された。

\section{結語}

吃音を自覚する成人 42 名を対象として吃音検査法 を施行し以下の結果を得た。

1. 重症度を調べたところ, 約 4 割が正常からごく 軽度であった。一方で，隠れ吃音についての検討の余 地が残された。

2.今回の対象者の $1 / 3$ が構音障害を重複し, その ほとんどが側音化構音障害であった。吃音の重症度と は関連はなかったが，側音化構音障害と吃音との関連 について, 今後もさらに精査が必要であると思われた。

3. 音読スピードが速い者は, 幼児期に吃音が発症 した可能性の割合が少ない傾向が考えられた，早口は 言い誤りも多く，また聞き手にとっては聞き取れない こともある。コミュニケーションの悪循環が生じやす い.

4. 吃音検查法の基本検查（絵の説明, 文章音読, 自由会話）について中核症状出現頻度と 1 秒当たりの 音読スピードを变数としたクラスター分析を行った。 その結果，4グループに区分され A から D グループ へと徐々に非流暢性は重症化していたが，必ずしも区 分されたグループと, 非流暢性頻度や重症度とは一致 しなかったＡグループでは音読が最も易しい課題 であり，逆にDグループでは音読は難しい課題でも あった。音読は改善や重症度を決めるキー項目と推察 された。

謝辞: 本研究にご協力くださった東京言友会, ならびに横浜 言友会の方々に深く御礼申し上げます。

利益相反自己申告：申告すべきものはありません，

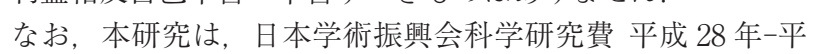
成 31 年基盤研究 (C), 課題番号 16K04405 研究課題名「吃音 症例のタイプ分類と認知神経心理学的介入の試み一脳活動デー 夕による効果判定」, 代表者 安崎文子の資金の一部を用いて遂
行した.

本論文の一部は, 2017 年 9 月 3 6 日ドイッ, ポツダム大学 にて行われたヨーロッパ認知心理学会にて発表した.

\section{文献}

1）小澤恵美, 原 由紀, 鈴木夏枝, 他：吃音検查法, 学苑社, 東京, 2013.

2) Canter GJ: Observations on neurogenic stuttering: a contribution to differential diagnosis. Br J Disord Commun, 6: 139-143, 1971.

3) Van Riper C: The Nature of Stuttering, 2nd ed, Waveland Press, Prospect Heights, Illinois, 1992.

4) Guitar B: Stuttering: An Integrated Approach to Its Nature and Treatment, 3rd ed, Lippincott Williams \& Wilkins, Philadelphia, 2006.

5) Månsson H: Childhood stuttering: Incidenc and development. J Fluency Disord, 25: 47-57, 2000.

6) Blumgart E, Tran $Y$ and Craig A: An investigation into the personal financial costs associated with stuttering. J Fluency Disord, 35: 203-215, 2010.

7）今井智子: 小児の構音障害一多様性への対応一, 音声言語 医学, $57: 359-366,2016$.

8）富里周太, 大石直樹, 浅野和海, 他：吃音に併存する発達 障害・精神神経疾患に関する検討。音声言語医学, 57 ： 7-11, 2016.

9) St. Louis K, Raphael L and Myeres F: Cluttering updated. ASHA Leader, 4: 20-22, 2003.

10) Preus A: Cluttering upgraded. J Fluency Disord, 21: 349358, 1996.

11) Oldfield RC: The assessment and analysis of handedness: the Edinburgh inventory. Neuropsychologia, 9: 97-113, 1971.

12）苅安 誠：吃音のブロック症状に対するリズム発話と運動 制御アプローチの効果. 音声言語医学, $31: 271-279$, 1990.

13）高橋正憲：利き手に関する一考察。総合リハビリテーショ ン, $38: 795-800,2010$.

14) Andrews G, Craig A, Feyer AM, et al: Stuttering: a review of research findings and theories circa 1982. J Speech Hear Disord, 48: 226-246, 1983.

15）菊池良和, 梅暗俊郎, 安達一雄, 他: 吃音を意識した年齢 に関する検討。音声言語医学，56：321-325，2015.

16) Yairi $\mathrm{E}$, Ambrose $\mathrm{N}$ and $\mathrm{Cox} \mathrm{N}$ : Genetics of stuttering: a critical review. J Speech Hear Res, 39: 771-784, 1996.

17）見上昌睦，森永和代：吃音者の学校教育期に打ける吃音の 変動と通常の学級の教師に対する配慮・支援の要望. 聴覚 言語障害, 34:61-81, 2006.

18) Tran $Y$, Blumgart $E$ and Craig A: Subjective distress associated with chronic stuttering. J Fluency Disord, 36: 17-26, 2011.

19) Blumgart E, Tran $Y$ and Craig A: Social anxiety disorder in adults who stutter. Depress Anxiety, 27: 687-692, 2010.

20) Hudock D, Dayalu VN, Saltuklaroglu T, et al: Stuttering 
inhibition via visual feedback at normal and fast speech rates. Int J Lang Commun Disord, 46: 169-178, 2011.

21) Nippold MA: Stuttering and phonology: Is there an interaction? Am J Speech Lang Pathol, 11: 99-110, 2002.

22) Terband H, Maassen B, Guenther FH, et al: Auditorymotor interactions in pediatric motor speech disorders: neurocomputational modeling of disordered development. J Commun Disord, 47: 17-33, 2014.

23）苅安 誠, 松平登志正, 外山 稔：コミュニケーション障 害と推定障害者数. 京都学園大学総合研究所報, 18 : 5560, 2017

24）後藤 守：構音発達を規定する諸要因の検討。教育心理学 研究, 19:75-84, 1971.

25）米田真弓，和田 健：口蓋裂異常構音における語音の弁別 に関する研究. 日口蓋裂会誌, 24：1-9, 1999.

26）千葉芙美子, 田中美郷：いわゆる機能的構音障害発症の原 因について。耳鼻臨床，69：1711-1717, 1976.

27）安崎文子, 出江紳一：兄妹で類似した機能的構音障害（声 門破裂音）のみられた症例一発達性発語失行の治療プログ ラムの有効性一. リハビリテーション医学, 39:492-496, 2002.

28）長澤泰子, 梅村正俊：側音化構音の Prevalence に関する 研究. 国立特殊教総研紀, 16：83-91，1989.
29）加藤正子, 岡崎恵子, 鈴木規子, 他：側音化構音の 5 症例. 音声言語医学, $22 ：$ 293-303, 1981.

30）加藤正子：側音化構音の動態について一エレクトロ歯冠パ ラトグラフによる観察—. 音声言語医学, 32:18-31, 1991.

31）小林宏明，早坂菊子：音韻障害を併せもつ吃音児の協調運 動発達 (2)一新規な運動の表出能力の検討一. 音声言語医 学, $43: 247-255,2002$.

32) Yairi E and Ambrose NG: Early childhood stuttering I: persistency and recovery rates. J Speech Lang Hear Res, 42: 1097-1112, 1999

33）宮本昌子：日本語版クラッタリングチェックリストの適用 可能性の検討。音声言語医学, $52: 322-328,2011$.

34) Anzaki F, Yamamoto $S$ and Inoue $M$ : Brain activities of a Japanese man with developmental stuttering in hearing and repetition tasks measured using functional nearinfrared spectroscopy. J Int Neuropsychol Soc, 22: 64, 2015.

別刷請求先：干158-8557 東京都世田谷区玉堤 1-28-1 東京都市大学大学院総合理工学研究科 安崎文子 